\title{
Comparison of OH concentration measurements by DOAS and LIF during SAPHIR chamber experiments at high $\mathrm{OH}$ reactivity and low NO concentration
}

\author{
H. Fuchs, H.-P. Dorn, M. Bachner, B. Bohn, T. Brauers, S. Gomm, A. Hofzumahaus, F. Holland, S. Nehr, F. Rohrer, \\ R. Tillmann, and A. Wahner \\ Institute of Energy and Climate Research, IEK-8: Troposphere, Forschungszentrum Jülich GmbH, Jülich, Germany \\ Correspondence to: H. Fuchs (h.fuchs@fz-juelich.de)
}

Received: 14 February 2012 - Published in Atmos. Meas. Tech. Discuss.: 6 March 2012

Revised: 31 May 2012 - Accepted: 15 June 2012 - Published: 11 July 2012

\begin{abstract}
During recent field campaigns, hydroxyl radical $(\mathrm{OH})$ concentrations that were measured by laser-induced fluorescence (LIF) were up to a factor of ten larger than predicted by current chemical models for conditions of high $\mathrm{OH}$ reactivity and low NO concentration. These discrepancies, which were observed in forests and urban-influenced rural environments, are so far not entirely understood. In summer 2011, a series of experiments was carried out in the atmosphere simulation chamber SAPHIR in Jülich, Germany, in order to investigate the photochemical degradation of isoprene, methyl-vinyl ketone (MVK), methacrolein (MACR) and aromatic compounds by $\mathrm{OH}$. Conditions were similar to those experienced during the PRIDE-PRD2006 campaign in the Pearl River Delta (PRD), China, in 2006, where a large difference between $\mathrm{OH}$ measurements and model predictions was found. During experiments in SAPHIR, OH was simultaneously detected by two independent instruments: LIF and differential optical absorption spectroscopy (DOAS). Because DOAS is an inherently calibration-free technique, DOAS measurements are regarded as a reference standard. The comparison of the two techniques was used to investigate potential artifacts in the LIF measurements for PRD-like conditions of $\mathrm{OH}$ reactivities of 10 to $30 \mathrm{~s}^{-1}$ and NO mixing ratios of 0.1 to $0.3 \mathrm{ppbv}$. The analysis of twenty experiment days shows good agreement. The linear regression of the combined data set (averaged to the DOAS time resolution, 2495 data points) yields a slope of $1.02 \pm 0.01$ with an intercept of $(0.10 \pm 0.03) \times 10^{6} \mathrm{~cm}^{-3}$ and a linear correlation coefficient of $R^{2}=0.86$. This indicates that the sensitivity of the LIF instrument is well-defined by its calibration procedure.
\end{abstract}

No hints for artifacts are observed for isoprene, MACR, and different aromatic compounds. LIF measurements were approximately $30-40 \%$ (median) larger than those by DOAS after MVK (20 ppbv) and toluene ( $90 \mathrm{ppbv}$ ) had been added. However, this discrepancy has a large uncertainty and requires further laboratory investigation. Observed differences between LIF and DOAS measurements are far too small to explain the unexpected high $\mathrm{OH}$ concentrations during the PRIDE-PRD2006 campaign.

\section{Introduction}

The hydroxyl radical, $\mathrm{OH}$, is the key reactant in the atmosphere that controls the removal of pollutants in the atmosphere (Finlayson-Pitts and Pitts Jr., 2000). Peroxy radicals $\mathrm{HO}_{2}$ and $\mathrm{RO}_{2}$, which are formed as products of the attack of $\mathrm{OH}$ on volatile organic compounds (VOCs), are responsible for the formation of photochemical ozone smog. The dominant primary source of $\mathrm{OH}$ radicals is the photolysis of ozone, nitrous acid and formaldehyde, so that $\mathrm{OH}$ concentrations are well correlated with solar UV radiation (e.g. Brauers et al., 2001; Rohrer and Berresheim, 2006). OH can be further enhanced by radical recycling following reactions of $\mathrm{OH}$ with VOCs (e.g. Lu et al., 2012a).

Global $\mathrm{OH}$ concentrations were estimated indirectly from the atmospheric budget of methyl chloroform (e.g. Bousqet et al., 2005; Prinn et al., 2005). However, in order to test directly atmospheric chemical mechanisms, in-situ measurements of $\mathrm{OH}$ are needed for comparison. For past

Published by Copernicus Publications on behalf of the European Geosciences Union. 
field measurements, model results and measurements agree mostly well within the combined uncertainties for clean and rural areas, and for urban environments with high $\mathrm{NO}_{\mathrm{x}}$ and high VOC concentrations (e.g. Monks et al., 2009; Whalley et al., 2010; Lu et al., 2012a,b). However, measured OH concentrations were found to be up to a factor of ten larger than model predictions in forested areas with low NO concentrations and large mixing ratios of several ppbvs of isoprene (Tan et al., 2001; Ren et al., 2008; Lelieveld et al., 2008; Kubistin et al., 2010; Pugh et al., 2010; Whalley et al., 2011). A large discrepancy between modeled and measured $\mathrm{OH}$ was also observed during the PRIDE-PRD2006 field campaign in the Pearl River Delta (PRD), China, at conditions with high VOC and low NO concentrations (Hofzumahaus et al., 2009; $\mathrm{Lu}$ et al., 2012a). In PRD, the $\mathrm{OH}$ reactivity had large daytime values ( 10 to $30 \mathrm{~s}^{-1}$ ), which were partly due to isoprene and its oxidation products, but also due to high concentrations of alkenes and aromatic compounds (Lou et al., 2010). The differences between observed and model calculated $\mathrm{OH}$ are not entirely understood (e.g. Lu et al., 2012a; Whalley et al., 2011). One reason could be that $\mathrm{OH}$ concentration measurements are influenced by interferences from organic compounds.

$\mathrm{OH}$ detection is difficult because atmospheric concentrations are small. Typical daytime concentrations are within the range of $10^{5}$ to $10^{7} \mathrm{~cm}^{-3}$, so that a very high instrument sensitivity is required. Moreover, high specificity is needed in order to avoid interferences from more abundant atmospheric trace gases. $\mathrm{OH}$ is lost on surfaces, requiring that contact of the sampled air with surfaces in the instrument must be avoided. Calibration of the instrument sensitivity remains the most difficult task, because accurately known $\mathrm{OH}$ concentrations must be produced by a radical source. Despite these challenges, a rising number of instruments performs measurements during field campaigns on a regular basis (Monks et al., 2009; Laj et al., 2009). Atmospheric $\mathrm{OH}$ can be directly detected by two methods: differential optical absorption spectroscopy (DOAS) and laser-induced fluorescence (LIF) (Heard and Pilling, 2003). Indirect detection is achieved by chemical ionization mass spectrometry (CIMS) after its conversion to sulfuric acid. Furthermore, $\mathrm{OH}$ can be determined indirectly in reaction chambers from the decay rate of VOCs that are oxidized by OH (e.g. Poppe et al., 2007; Barmet et al., 2012). DOAS is the only absolute detection method that does not require calibration of the instrument sensitivity (Dorn et al., 1995). Therefore, DOAS is regarded as a reference standard (Schlosser et al., 2007, 2009). LIF is the most commonly used technique, and such instruments were deployed during field campaigns when large differences between measurements and model prediction were observed. Therefore, the question arises whether LIF instruments may suffer from any unidentified interference in the presence of high VOC concentrations and low NO.

Comparison of measurements from different instruments is one possibility to check the quality of measurements because two instruments unlikely suffer from identical systematic errors, especially if different detection techniques are applied. Therefore, several comparison efforts were conducted in the past (Beck et al., 1987; Campbell et al., 1995; Brauers et al., 1996; Mount et al., 1997; Hofzumahaus et al., 1998; Eisele and Tanner, 1991; Eisele et al., 2001; Schlosser et al., 2007, 2009). In general, these exercises demonstrated progress in the data quality of measured $\mathrm{OH}$ over the years. The last comparison (HOxCOMP) was conducted during experiments in the atmosphere simulation chamber SAPHIR in Jülich, Germany, in summer 2005 (Schlosser et al., 2009). Chamber measurements from three different LIF instruments (from Forschungszentrum Jülich, Germany; Max-Planck Institute for Chemistry, Mainz, Germany; Frontier Research Center for Global Change, Yokohama, Japan) and the Jülich DOAS instrument were compared in this campaign. The main result was that measurements by all LIF instruments agreed with those by DOAS within $13 \%$. This is consistent with the $1 \sigma$ accuracy of LIF calibrations (10-20\%). Furthermore, experiments which were designed to identify potential interferences from ozone, $\mathrm{NO}_{\mathrm{x}}$, and water vapor gave no hints for artifacts in the measurements. However, no previous $\mathrm{OH}$ comparison was dedicated to investigate the instrument performances at high VOC loadings and low $\mathrm{NO}_{\mathrm{x}}$ concentrations, for which the largest discrepancies between model prediction and measurements were found in later field campaigns.

In summer 2011, an extended series of experiments was conducted in the atmosphere simulation chamber SAPHIR. Experiments were designed to study the photochemical degradation of isoprene and its first-generation products methacrolein (MACR) and methyl-vinyl-ketone (MVK), and of several aromatic compounds. The Jülich LIF and DOAS instruments simultaneously measured $\mathrm{OH}$ concentrations. NO mixing ratios were kept as low as possible (approximately $0.2 \mathrm{ppbv}$ ) and VOC concentrations were chosen to reproduce the high $\mathrm{OH}$ loss rates, which were encountered during the PRIDE-PRD2006 campaign (up to $30 \mathrm{~s}^{-1}$ ). Here, the performance of the LIF instrument is compared to that of DOAS, and the potential for artifacts in LIF measurements for the specific conditions of high $\mathrm{OH}$ reactivity and low NO concentration is investigated.

\section{Experimental setup}

\subsection{Differential Optical Absorption Spectroscopy (DOAS)}

The unique Jülich DOAS instrument was deployed in field experiments in the past (Brandenburger et al., 1998; Brauers et al., 2001) and is now permanently installed in SAPHIR. It provides inherently calibration-free measurements of tropospheric $\mathrm{OH}$ radicals with an $1 \sigma$ accuracy of $6.5 \%$ (Hausmann et al., 1997) and is therefore accepted as a reference 
technique for $\mathrm{OH}$. Besides $\mathrm{OH}$, also formaldehyde, sulfur dioxide, and naphthalene can be simultaneously detected.

Details of the instrument can be found elsewhere (Hausmann et al., 1997; Schlosser et al., 2007, 2009). The output of a dye laser $(616.08 \mathrm{~nm}$, pulse duration $800 \mathrm{fs})$ is frequency doubled in an external BBO crystal to generate broad-band $\mathrm{UV}$ radiation at $308.04 \mathrm{~nm}$ with a bandwidth of approximately $0.5 \mathrm{~nm}$. The dye laser is synchronously pumped by a picosecond, passively mode-locked, diode-pumped Nd:YAG laser with internal frequency doubling to $532 \mathrm{~nm}$. The repetition rate is $82.2 \mathrm{MHz}$ with a timing jitter of less than $1 \mathrm{~Hz}$ controlled by a phase-locked-loop feedback system. The absorption signal is detected using a high resolution Echelle spectrometer $(\Delta \lambda=2.7 \mathrm{pm}, f=1.5 \mathrm{~m})$, which is coupled to a cooled photodiode array detector. The spectral detection interval of $0.25 \mathrm{~nm}$ comprises five $\mathrm{OH}$ absorption lines.

The absorption path in the SAPHIR chamber has a length of $2240 \mathrm{~m}$ and is realized by an optical multiple reflection cell (modified White cell type), whose mirrors have a distance of $20 \mathrm{~m}$. The UV laser power is held well below 1$2 \mathrm{~mW}$ in order to suppress significant self-generation of $\mathrm{OH}$ radicals, which can be produced by the UV radiation field within the White cell at high ozone concentrations. Additionally, the level of $\mathrm{OH}$ is checked at the end of each experiment when the chamber roof is closed and the $\mathrm{OH}$ concentration is expected to be zero.

The detection limit and the precision of each measurement is mainly limited by the residual structures in the spectra. Absorption spectra are evaluated using the multichannel scanning technique (Brauers et al., 1995), which enables the detection of minimal optical densities of the order of $1 \times 10^{-5}$ (RMS) in $100 \mathrm{~s}$ integration time (Table 1). The total measurement time for one data point is about $200 \mathrm{~s}$ due to the acquisition time of the spectra, time needed to turn the spectrograph's grating, and additional computing time. The precision of each single measurement is calculated from the spectral residuum as described in Hausmann et al. (1999). A statistical analysis of spectra acquired during zero air periods of experiments in 2011 revealed a mean $1 \sigma$ detection limit of $7.3 \times 10^{5} \mathrm{~cm}^{-3}$.

The accuracy of tropospheric $\mathrm{OH}$ measurements by longpath absorption spectroscopy is ultimately limited by the uncertainty of the effective $\mathrm{OH}$ absorption cross section. The latter was determined from calculated spectra for the $A^{2} \Sigma^{+}$, $v^{\prime}=0 \leftarrow X^{2} \Pi, v^{\prime \prime}=0$ band at $308 \mathrm{~nm}$. The line shape calculations took into account the published Einstein coefficients for spontaneous emission, Doppler broadening, the collision line broadening by air molecules, and the broadening caused by the width and shape of the instrumental response function of the spectrograph. The absolute values of the absorption lines were scaled to the fluorescence lifetime of $\mathrm{OH}$, for which three measurements were published, agreeing within $3 \%$ (Dorn et al., 1995).

The accuracy and long-term stability of the line shape calculation was frequently controlled by comparison of
Table 1. Performance of the Jülich LIF and DOAS instruments during experiments in SAPHIR in summer 2011.

\begin{tabular}{lll}
\hline & DOAS & LIF \\
\hline integration time/s & 100 & 18 \\
measurement time $/ \mathrm{s}$ & 205 & 47 \\
$1 \sigma$ precision $/ 10^{6} \mathrm{~cm}^{-3}$ & 0.8 & 0.3 \\
$1 \sigma$ accuracy $/ \%$ & 6.5 & 10 \\
\hline
\end{tabular}

measured $\mathrm{OH}$ with the calculated $\mathrm{OH}$ spectra according to Hausmann et al. (1997). For this purpose OH radicals were formed in the SAPHIR chamber in front of the end mirrors of the multiple reflection cell by photolysis of water vapor at $185 \mathrm{~nm}$ using a mercury pen-ray lamp. The mean total uncertainty of the DOAS OH measurement is $6 \%$ and covers the $\mathrm{OH}$ lifetime measurements ( $3 \%)$, the line shape calculation $(2 \%)$, and optical path length plus spectral filtering effects (1\%) (Hausmann et al., 1997).

\subsection{Laser-Induced Fluorescence (LIF)}

LIF is an established technique for the detection of $\mathrm{OH}$ radicals (Schlosser et al., 2009). Although the principle of detection is the same for all instruments, the design differs among the instruments deployed in field campaigns. The Jülich LIFinstruments are described in detail by Holland et al. (2003); Lu et al. (2012a) and Fuchs et al. (2011). Air is sampled through a conical shaped inlet nozzle (orifice $0.4 \mathrm{~mm}$ ) and is expanded into a detection cell operated at low pressure $(3.5 \mathrm{hPa})$. $\mathrm{OH}$ radicals are excited at $308 \mathrm{~nm}$ by a short laser pulse $(25 \mathrm{~ns})$ with a high repetition rate of $8.5 \mathrm{kHz}$. The volume where the laser pulse crosses the flow of sampled air is approximately $10 \mathrm{~cm}$ downstream of the inlet nozzle. Laser light is provided by a Nd:YAG laser $(532 \mathrm{~nm})$ pumped dye-laser system. The output of the dye-laser at $616 \mathrm{~nm}$ is frequency-doubled by a nonlinear optical crystal (BBO). The wavelength of the dye laser is periodically shifted from onresonance wavelengths of the $\mathrm{OH}$ absorption line to offresonance wavelengths in order to distinguish between background and fluorescence signals. The fluorescence light is imaged onto an MCP (multichannel plate) photo-detector and measured by gated single-photon counting electronics. In order to lock the wavelength of the laser for an automatic correction of wavelengths drifts, the $\mathrm{OH}$ fluorescence is monitored in a reference cell, in which high $\mathrm{OH}$ concentrations are produced by water vapor photolysis at $185 \mathrm{~nm}$. One cycle between on and off-resonance wavelengths gives one data point including $18 \mathrm{~s}$ integration time of fluorescence counting (Table 1). The time resolution is approximately $47 \mathrm{~s}$ due to the additional time for the background signal measurement and for data computing.

The precision of the $\mathrm{OH}$ measurements is limited by the shot noise of the detected $\mathrm{OH}$ fluorescence and the subtracted background signals. In the first half of the campaign, 
the background signal often exceeded the $\mathrm{OH}$ fluorescence signal and caused relatively large noise in the $\mathrm{OH}$ measurements because the time delay between the laser pulse and the start of the $\mathrm{OH}$ fluorescence detection was not well adjusted. After optimization of the time delay, the measurement noise was significantly reduced and a $1 \sigma$ detection limit of $0.3 \times 10^{6} \mathrm{~cm}^{-3}$ was achieved. In the sunlit chamber, solar stray light enters the fluorescence cell through the inlet nozzle and significantly contributes to the background signal and its shot noise. Because of the high variability of sunlight, its contribution to the background signal is measured with high precision during a second, longer time window after the fluorescence has diminished. In summer 2011, the influence of sunlight was reduced for part of the experiments by a ringshaped shield that shaded the tip of the inlet nozzle over the course of the day.

Calibration of the LIF instrument is achieved by a radical source, in which $\mathrm{OH}$ radicals are produced by water vapor photolysis at $185 \mathrm{~nm}$. The $\mathrm{OH}$ concentration is calculated from measurements of humidity, flow rate and light intensity. The latter is measured with a phototube regularly calibrated against an $\mathrm{O}_{3} / \mathrm{O}_{2}$ actinometry. Details of the design of the calibration source and the calibration procedure and evaluation can be found elsewhere (Aschmutat et al., 1994; Holland et al., 2003; Fuchs et al., 2011). The $1 \sigma$ accuracy of the calibration is $10 \%$ (Table 1). During this campaign, calibration measurements were performed every 3 to 5 days, sometimes directly after an experiment. The $1 \sigma$ reproducibility of the calibration was approximately $\pm 5 \%$ for a time span of two weeks. However, the instrument sensitivity increased slowly by $25 \%$ over the duration of the campaign ( 3 months) for unknown reasons.

All data are corrected for changes of the sensitivity due to quenching of the $\mathrm{OH}$ fluorescence by water vapor using rate constants from the literature (Heard and Henderson, 2000). In summer 2011, calibration measurements were always performed at several different water vapor concentrations, showing that the application of this correction is justified.

It is known that ozone photolysis at $308 \mathrm{~nm}$ in the presence of water vapor can lead to artificial $\mathrm{OH}$ production in the fluorescence cell. This interference is minimized by (1) rapid exchange of the sampled air in the LIF detection volume between consecutive laser shots, and (2) a sheath flow of clean nitrogen, which purges the background volume in the detection cell. Test measurements done after this campaign showed that an ozone interference was insignificant (less than $4 \times 10^{5} \mathrm{~cm}^{3}$ at $50 \mathrm{ppbv}$ ozone) for the experiments in this work. This is consistent with earlier results showing that the ozone interference is typically within the range of a few $10^{5} \mathrm{~cm}^{-3}$ for an ozone mixing ratio of $50 \mathrm{ppbv}$ (Schlosser et al., 2009).

\subsection{Experiments in SAPHIR}

The atmosphere simulation chamber SAPHIR allows investigation of chemical processes under conditions typically found in the troposphere. Instrument comparison campaigns in SAPHIR showed that different instruments sample the same trace gas and radical concentrations, providing evidence that the chamber is suitable for this type of experiments (Schlosser et al., 2007, 2009; Apel et al., 2008; Fuchs et al., 2009, 2010a,b).

SAPHIR consists of a double-wall Teflon (FEP) film of cylindrical shape (length $18 \mathrm{~m}$, diameter $5 \mathrm{~m}$, volume $270 \mathrm{~m}^{3}$ ). Slight overpressure prevents leakages of outside air into the chamber. The chamber can be exposed to sunlight by opening its roof. The Teflon film has a good transmittance over the entire solar spectrum. Ultra pure synthetic air is provided from mixing evaporated, ultra-pure liquid nitrogen and oxygen. The chamber air can be humidified by evaporating Milli-Q water, which is added together with a large flow of synthetic air. A more detailed description of the chamber and its properties can be found elsewhere (Rohrer et al., 2005; Bohn et al., 2005).

The experiments carried out in summer 2011 were designed to simulate conditions similar to those encountered during PRIDE-PRD2006. OH concentration reached values up to $2 \times 10^{7} \mathrm{~cm}^{-3}$, ozone was kept mostly within the range of 40 to $50 \mathrm{ppbv}$, $\mathrm{NO}$ was typically between 0.1 to $0.2 \mathrm{ppbv}$ and the $\mathrm{OH}$ reactivity of added VOCs was within the range of 10 to $30 \mathrm{~s}^{-1}$ (Table 2). A large set of instruments measured trace gas concentrations, aerosol properties and physical parameters. Measurements included: NO and $\mathrm{NO}_{2}$ (both chemiluminescence), $\mathrm{O}_{3}$ (chemiluminescence detectors), $\mathrm{OH}$ (DOAS, LIF), $\mathrm{HO}_{2}$ and $\mathrm{RO}_{2}$ (LIF), VOCs (GC, PTRMS), $\mathrm{H}_{2} \mathrm{O}$, and $\mathrm{CH}_{4}$ (CRDS), $\mathrm{OH}$ reactivity (laser flash photolysis + LIF), and photolysis frequencies (spectroradiometer).

Figure 1 shows two examples for sequences of trace gas additions in this campaign. Experiments started after the chamber had been flushed with synthetic air overnight, so that trace gas concentrations were below the limit of detection of instruments in the morning. First of all, the air was humidified and the chamber was exposed to sunlight. Ozone was injected in most of the experiments and was relatively constant during an experiment. No other trace gas was added for approximately two hours in order to observe the amount of nitrous acid (HONO), formaldehyde and acetaldehyde, which are formed in the chamber from unknown sources at these conditions. Photolysis of HONO served as primary source for $\mathrm{NO}_{\mathrm{x}}$ and $\mathrm{OH}$ (Rohrer et al., 2005). The continuous formation of $\mathrm{HONO}$ led to increasing $\mathrm{NO}_{\mathrm{x}}$ mixing ratios with maximum mixing ratios of 0.5 to 2 ppbv over the course of an experiment (Table 2). $\mathrm{No} \mathrm{NO}_{\mathrm{x}}$ was added during the experiments. NO mixing ratios were relatively stable between 100 and 200 pptv (Table 2). $\mathrm{HO}_{2}$ concentrations were between $1 \times 10^{8}$ and $2 \times 10^{9} \mathrm{~cm}^{-3}$, similar to peroxy radical 

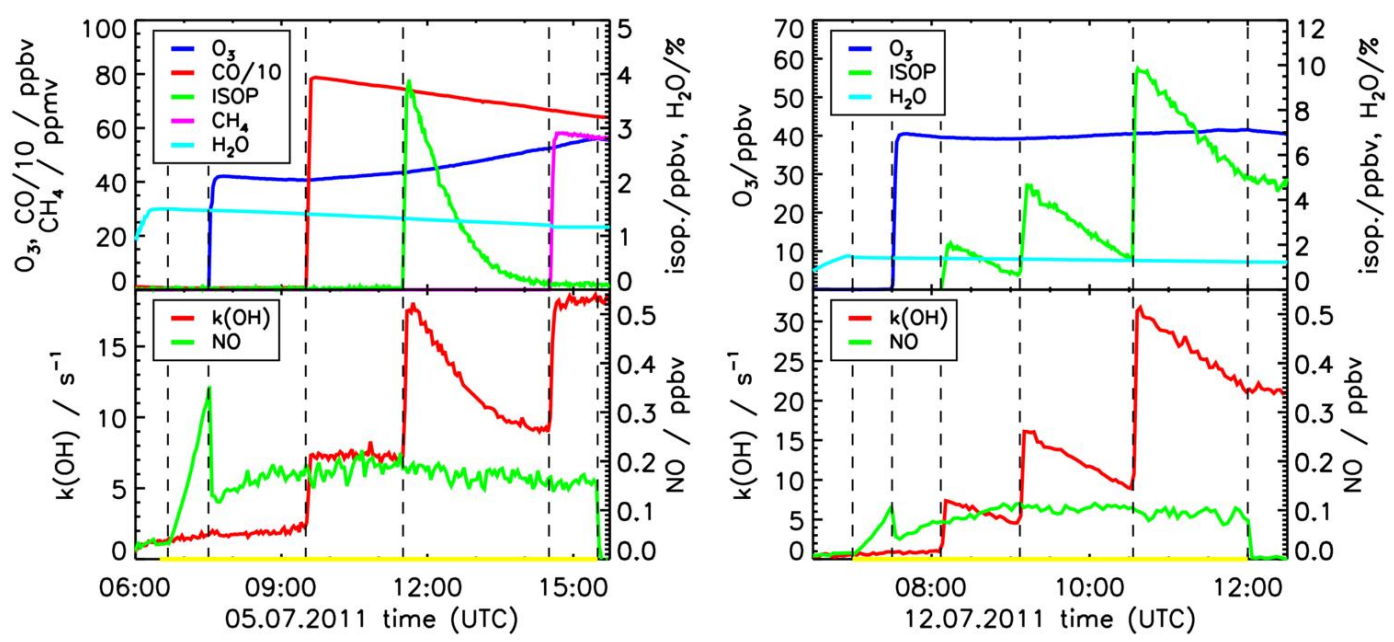

Fig. 1. Typical sequence of trace gas additions during experiments. The organic compound of interest (here isoprene) was injected either once (left panel) or several times (right panel). Dashed vertical lines indicate times when trace gases were injected or the chamber roof was opened or closed. The period of time when the chamber was illuminated by sunlight is shown by horizontal yellow lines.

concentration during PRIDE-PRD2006. After the initial period, reactants for $\mathrm{OH}$ were added to the chamber air in order to observe their photochemical degradation. One or more injections of $\mathrm{CO}$ and/or VOCs were done, depending on the purpose of the experiment and the chemical lifetime of the VOC (Fig. 1). Experiments focused either on the degradation of isoprene (6 experiments) and its first-generation products MVK ( 2 experiments) and MACR (3 experiments) or on the degradation of aromatic compounds (\# experiments): benzene (1), toluene (1), mesitylene (2), p-xylene (1). One experiment was conducted with t-butene. During three other experiments, which served as reference experiments, no organic compound or only $\mathrm{CO}$ was added.

\section{Results}

In order to investigate the precision of $\mathrm{OH}$ measurements, those data are analyzed at their original time resolution which were acquired during morning hours after the chamber had been flushed overnight and before the chamber roof was opened and trace gases were added. During these periods the $\mathrm{OH}$ concentration is expected to be zero. For the LIF instrument only data from the second half of the campaign were taken after the timing of the photon counting was optimized in order to reduce the background signal (see Sect. 2.2). Figure 2 shows the Allan deviation plot that gives a measure of the $1 \sigma$ precision dependent on the measurement time when measurements are averaged. At the minimum measurement time of $205 \mathrm{~s}$ and $47 \mathrm{~s}$, including $100 \mathrm{~s}$ and $18 \mathrm{~s}$ integration time, a $1 \sigma$ precision of 0.8 and $0.3 \times 10^{6} \mathrm{~cm}^{-3}$ is achieved for DOAS and LIF measurements, respectively. According to the Allan deviation plot (Fig. 2), the precision of LIF measurement would be approximately $0.15 \times 10^{6} \mathrm{~cm}^{-3}$ if measurements were averaged to the minimum measurement time

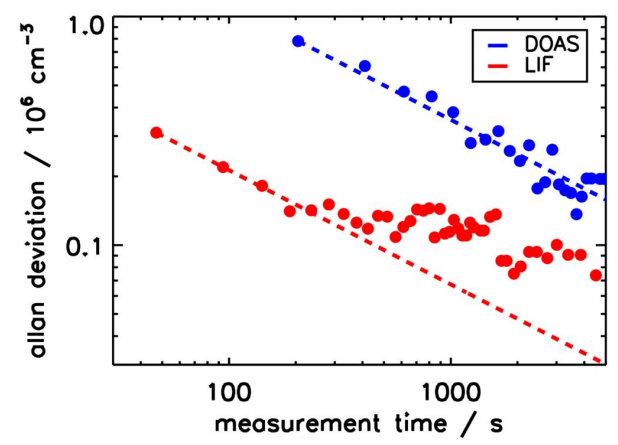

Fig. 2. Allan deviation ( $1 \sigma$ precision) of measurements by DOAS and LIF. Calculations include measurements that were acquired in the clean, dark chamber, before the roof was opened. For the LIF instrument, only data are included after optimization of the instrument's background signal (see text for details). Lines give the trend in the Allan deviation, which would be expected if measurements were distributed like Gaussian noise (inverse square-root dependence on the measurement time).

of the DOAS instrument. The precision of LIF measurements analyzed here is achieved in the absence of sunlight. As discussed above, sunlight also contributes to the background signal. It is approximately twice as large (even with the additional shield, see above) for clear sky and smallest zenith angle of the sun, so that the precision of data is lower than in the dark.

Figure $3 \mathrm{a}$ and $\mathrm{b}$ show diurnal variations of the $\mathrm{OH}$ concentration for all experiments ( $300 \mathrm{~s}$ average data) together with the ozone photolysis frequency, $j\left(\mathrm{O}^{1} \mathrm{D}\right)$, as a proxy for the strength of solar radiation. The times when reactants were added are marked by dashed vertical lines. The panels are grouped according to the added reactant. The diurnal 

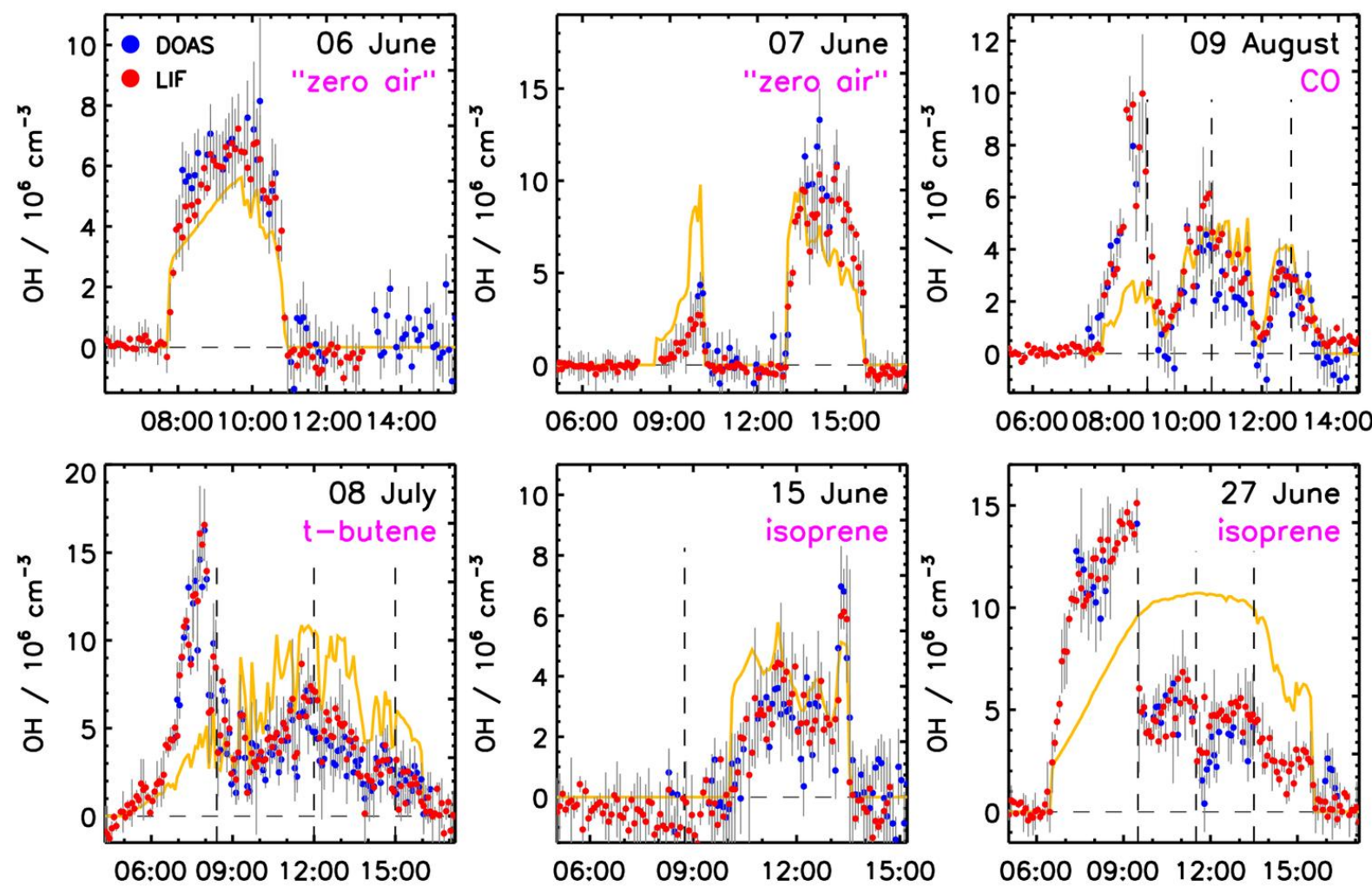

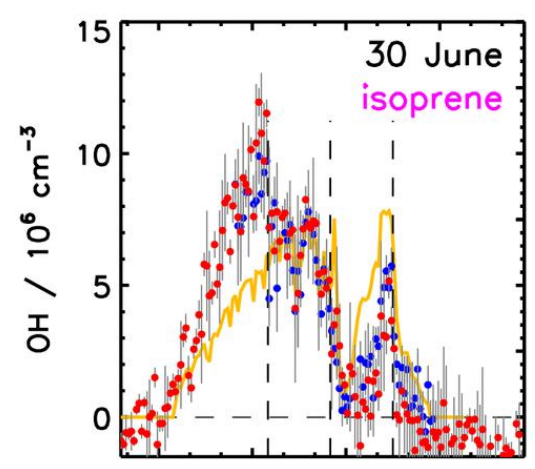

06:00 09:00 12:00 15:00

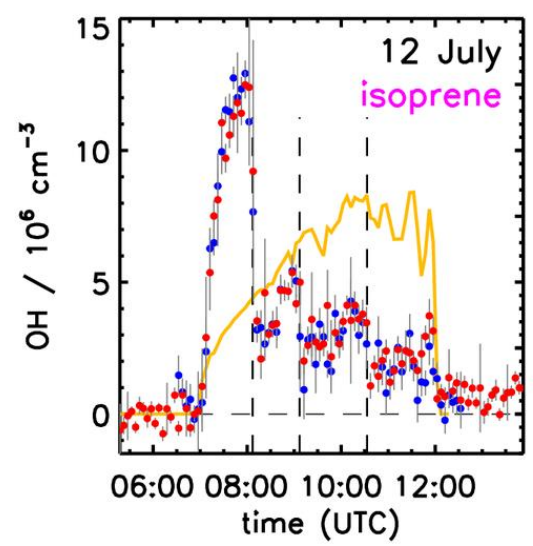

\footnotetext{
Fig. 3. Caption on next page.
}
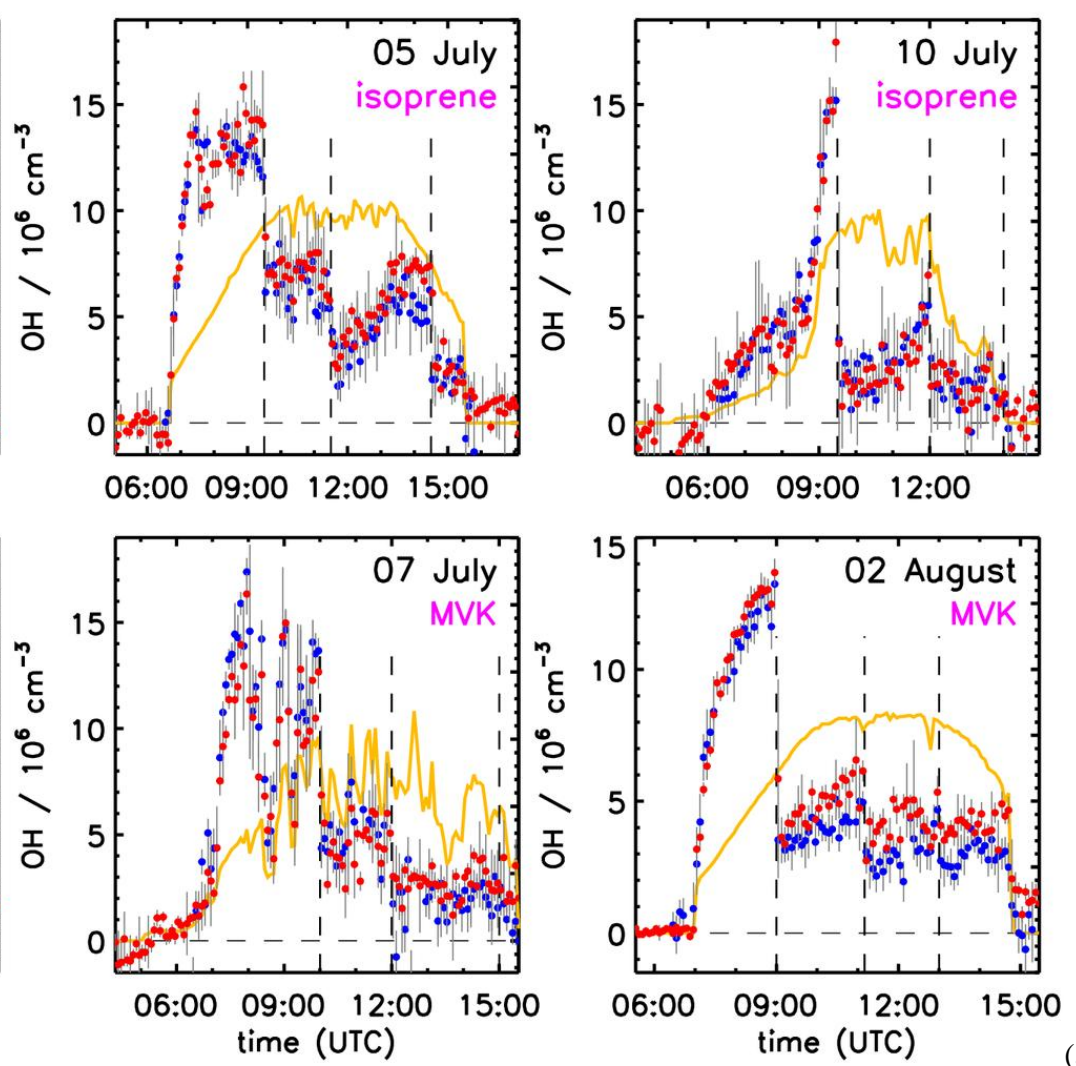

(a) 

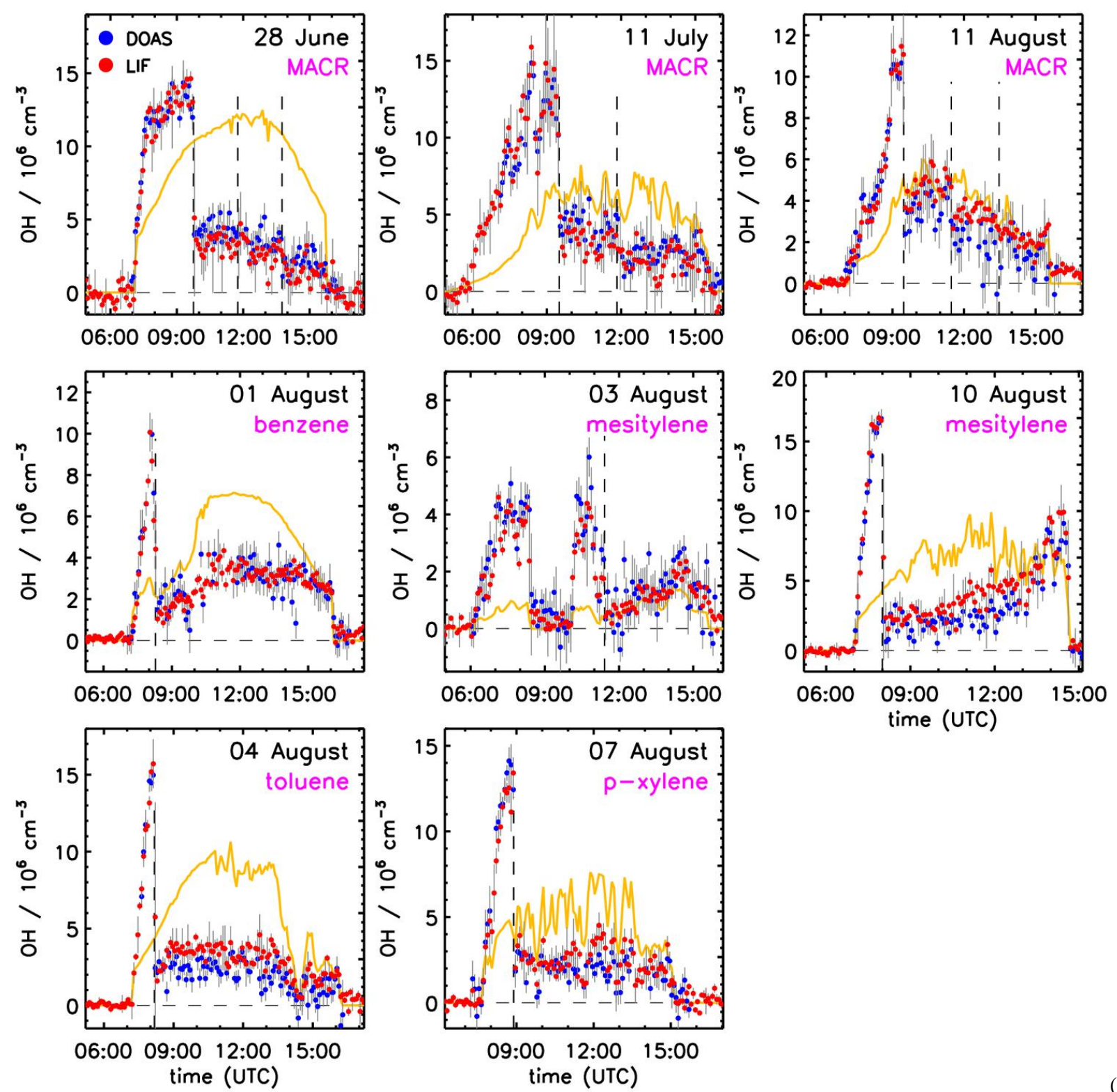

Fig. 3. Diurnal profiles of OH concentration measurements by DOAS and LIF ( $300 \mathrm{~s}$ average). Grey bars are $1 \sigma$ errors of measurements. Yellow lines give the ozone photolysis frequency, $j\left(\mathrm{O}^{1} \mathrm{D}\right)$, inside the chamber (y-axis is scaled from 0 to $3 \times 10^{-5} \mathrm{~s}^{-1}$ in each plot). Dashed vertical lines indicate the time when $\mathrm{OH}$ reactants were added. No $\mathrm{OH}$ reactant was added during "zero air" experiments.

variation of $\mathrm{OH}$ can be qualitatively understood by changes in the radiation and in the concentration of reactants for $\mathrm{OH}$, which determine the $\mathrm{OH}$ production and loss rate, respectively (Ehhalt and Rohrer, 2000).

$\mathrm{OH}$ concentrations measured by DOAS and LIF mostly agree, as can be seen in Fig. 3a and b. The scatter in the LIF data is smaller for experiments in August when the background signal was reduced (see above). Before this optimization, LIF measurements sometimes returned systematically negative values for the difference of on- and off-resonance count rates when the chamber roof was closed at the end of an experiment (e.g. 30 June, 15:00 UTC). A possible explanation for this observation is a small but systematic change of the laser beam alignment in the fluorescence cell when the laser wavelength is tuned between on- and off-resonance positions. This change may have caused the observed increase of the laser-generated background signal in the off-resonance position. This conclusion is based on the analysis of the laser beam position behind the fluorescence cell, which was monitored with a position-sensitive photodiode. This effect is not significant for small background signals when LIF measurements are more precise. 
Table 2. Chemical conditions during experiments in SAPHIR when LIF and DOAS measured together. Maximum values are denoted if no range is given. $\mathrm{NO}, \mathrm{O}_{3}, \mathrm{CO}$, and $\mathrm{H}_{2} \mathrm{O}$ mixing ratios were relatively constant over the course of an experiment. $\mathrm{CO}$ mixing ratios are only noted if $\mathrm{CO}$ was added during the experiment. Methane (50 to $60 \mathrm{ppmv})$ was added in some experiments for the last 1 to $2 \mathrm{~h}$. $k(\mathrm{OH})$ is the measured total $\mathrm{OH}$ reactivity including reactivity from added reactants, background reactivity in the chamber and the reactivity of products of the VOC degradation. If ozone was added during the experiment, NO concentrations are given for the period after the ozone addition when the photostationary state between $\mathrm{O}_{3}$ and $\mathrm{NO}_{2}$ was established.

\begin{tabular}{|c|c|c|c|c|c|c|c|c|c|c|}
\hline experiment & $\begin{array}{l}\text { VOC/ } \\
\text { ppbv }\end{array}$ & $10^{6} \mathrm{~cm}^{\mathrm{OH} /}$ & $\begin{array}{r}k(\mathrm{OH}) / \\
\mathrm{s}^{-1}\end{array}$ & $\begin{array}{l}\mathrm{NO}_{\mathrm{x}} \\
\mathrm{ppbv}\end{array}$ & $\begin{array}{l}\mathrm{NO} / \\
\mathrm{pptv}\end{array}$ & $\begin{array}{c}\mathrm{O}_{3} / \\
\mathrm{ppbv}\end{array}$ & $\begin{array}{c}\mathrm{H}_{2} \mathrm{O} / \\
\%\end{array}$ & $\begin{array}{l}\mathrm{CO} / \\
\mathrm{ppbv}\end{array}$ & $\begin{array}{l}\mathrm{T/} \\
{ }^{\circ} \mathrm{C}\end{array}$ & date \\
\hline zero air ${ }^{\mathrm{a}}$ & n.a. & 7.5 & 2 & 0.3 & $50-100$ & 3 & 1.6 & n.a. ${ }^{b}$ & $18-33$ & 6 June \\
\hline zero air ${ }^{\mathrm{a}}$ & n.a. & 14 & 2 & 0.5 & $50-250$ & 7 & 1.4 & n.a. ${ }^{b}$ & $13-22$ & 7 June \\
\hline $\mathrm{CO}$ & n.a. & 11 & 15 & 1.6 & $50-200$ & 49 & 1.4 & 2200 & $14-22$ & 9 August \\
\hline t-butene & $7.5^{\mathrm{c}}$ & 18 & 20 & 1.8 & $100-300$ & 52 & 1.7 & 1050 & $17-33$ & 8 July \\
\hline \multirow[t]{6}{*}{ isoprene } & 8 & 6.5 & 18 & 0.5 & $20-100$ & 34 & 1.4 & n.a. ${ }^{b}$ & $15-30$ & 15 June \\
\hline & $7^{\mathrm{c}}$ & 14 & 24 & 1.9 & $150-200$ & 70 & 1.7 & 1550 & $27-38$ & 27 June \\
\hline & $5^{c}$ & 11 & 21 & 2.0 & $100-300$ & 52 & 1.7 & 800 & $20-27$ & 30 June \\
\hline & $4.6^{\mathrm{c}}$ & 13 & 18 & 1.6 & 130-190 & 57 & 1.5 & 800 & $25-35$ & 5 July \\
\hline & 4.5 & 17 & 31 & 1.8 & $100-250$ & 62 & 2.5 & 4300 & $16-30$ & 10 July \\
\hline & 11 & 13 & 31 & 0.9 & 80-110 & 42 & 1.5 & n.a. ${ }^{b}$ & $20-33$ & 12 July \\
\hline \multirow[t]{2}{*}{ MVK } & $21^{\mathrm{c}}$ & 20 & 25 & 1.2 & $100-220$ & 43 & 1.6 & 850 & $25-30$ & 7 July \\
\hline & 20 & 13 & 17 & 1.3 & 80-130 & 56 & 1.8 & n.a. ${ }^{b}$ & $24-34$ & 2 August \\
\hline \multirow[t]{3}{*}{ MACR } & $15^{\mathrm{c}}$ & 14 & 26 & 1.7 & $120-200$ & 55 & 2.0 & 1550 & $30-40$ & 28 June \\
\hline & 15 & 15 & 20 & 1.6 & $100-200$ & 42 & 1.7 & 850 & $22-31$ & 11 July \\
\hline & 20 & 12 & 14 & 0.9 & $70-100$ & 46 & 1.7 & n.a. ${ }^{b}$ & $19-28$ & 11 August \\
\hline benzene & 250 & 10 & 13 & 0.8 & $110-200$ & 18 & 0.9 & n.a. ${ }^{b}$ & $20-30$ & 1 August \\
\hline mesitylene & 4.2 & 5.5 & 10 & 0.5 & $50-170$ & 4.5 & 1.8 & n.a. ${ }^{b}$ & $20-24$ & 3 August \\
\hline mesitylene & 5 & 17 & 11 & 0.7 & $50-120$ & 16 & 1.2 & n.a. ${ }^{b}$ & $18-26$ & 10 August \\
\hline toluene & 90 & 16 & 21 & 0.7 & $70-220$ & 20 & 1.8 & n.a. ${ }^{b}$ & $24-33$ & 4 August \\
\hline p-xylene & 24 & 15 & 15 & 0.8 & $90-320$ & 19 & 1.5 & n.a. ${ }^{b}$ & $19-26$ & 7 August \\
\hline
\end{tabular}

${ }^{\mathrm{a}}$ No addition of $\mathrm{OH}$ reactants. ${ }^{\mathrm{b}}[\mathrm{CO}]<20$ ppbv. ${ }^{\mathrm{c}}$ Methane addition at the end of the experiment.

The qualitatively good agreement between measurements of both instruments is analyzed more quantitatively by a correlation and regression analysis (Table 3 and Figs. 4 and 5a to b). Here, LIF measurements, which have a higher time resolution than those by DOAS, are averaged to the time grid of the DOAS measurements. As expected from the diurnal variations, LIF and DOAS data are correlated as indicated by the values of the linear correlation coefficient, $R^{2}$, which ranges between 0.57 and 0.96 for individual experiments and which is 0.86 for the combined data set. $R^{2}$ is in the lower range when maximum $\mathrm{OH}$ concentrations are only a few $10^{6} \mathrm{~cm}^{-3}$.

The results from a linear regression analysis, which takes errors in both $\mathrm{OH}$ measurements into account (Press et al., 1992), are also shown in Table 3 and Figs. 4 and 5a to b. The regression of the combined data set gives a slope of $1.02 \pm 0.01$, which is consistent with the accuracy of measurements, and an intercept of $(0.10 \pm 0.03) \times 10^{6} \mathrm{~cm}^{-3}$, which is below the limit of detection of the instruments (Table 1). The regression for an individual experiment results in slopes within the range of 0.84 and 1.27 and maximum intercepts of $\pm 1 \times 10^{6} \mathrm{~cm}^{-3}$. The sum of squared residuals is within the range of the number of data points $\left(\chi^{2} /(N-2)\right.$ in Table 3), indicating that the relationship between LIF and DOAS data is consistent with a linear behavior within their errors. The regression parameters are less well-defined if either the data set does not include a sufficient number of data points, especially for zero $\mathrm{OH}$ concentrations, or the dynamic range of $\mathrm{OH}$ measurements is only a few times larger than the statistical error of measurements. These effects may explain why largest deviations of the slope from unity and largest intercepts were calculated for experiments (1) on 15 June and 3 August when maximum $\mathrm{OH}$ concentrations were only a few $10^{6} \mathrm{~cm}^{-3}$, (2) on 7 June when the number of data points was small, and (3) on 30 June, 7 and 11 July when only few measurements close to zero $\mathrm{OH}$ were acquired.

\section{Discussion}

The results of the correlation and regression analysis of this campaign are consistent with results from earlier 
Table 3. Linear correlation (correlation coefficient $R^{2}$ ) and regression analysis (LIF vs. DOAS) of data (time resolution of DOAS data, number of data points $N$ ) for each experiment and the entire data set. Errors of the fit parameters are $1 \sigma$ errors. $\frac{\chi^{2}}{N-2}$ is the sum of squared residuals divided by the degrees of freedom $(N-2)$.

\begin{tabular}{|c|c|c|c|c|c|c|}
\hline experiment & slope & intercept $/ 10^{6} \mathrm{~cm}^{-3}$ & $\frac{\chi^{2}}{N-2}$ & $R^{2}$ & $N$ & date \\
\hline zero air* & $1.02 \pm 0.05$ & $-0.6 \pm 0.3$ & 1.1 & 0.87 & 45 & 6 June \\
\hline zero air* & $0.88 \pm 0.04$ & $-0.2 \pm 0.2$ & 0.7 & 0.96 & 46 & 7 June \\
\hline $\mathrm{CO}$ & $0.99 \pm 0.06$ & $0.7 \pm 0.1$ & 1.0 & 0.76 & 97 & 9 August \\
\hline t-butene & $0.98 \pm 0.03$ & $0.4 \pm 0.2$ & 1.3 & 0.83 & 171 & 8 July \\
\hline \multirow[t]{6}{*}{ isoprene } & $1.22 \pm 0.09$ & $-0.6 \pm 0.2$ & 1.3 & 0.57 & 86 & 15 June \\
\hline & $1.08 \pm 0.05$ & $-0.3 \pm 0.3$ & 1.5 & 0.79 & 71 & 27 June \\
\hline & $1.27 \pm 0.04$ & $-1.2 \pm 0.2$ & 1.5 & 0.84 & 108 & 30 June \\
\hline & $1.02 \pm 0.04$ & $0.5 \pm 0.2$ & 1.5 & 0.86 & 155 & 5 July \\
\hline & $1.03 \pm 0.04$ & $-0.3 \pm 0.2$ & 1.4 & 0.80 & 135 & 10 July \\
\hline & $1.01 \pm 0.03$ & $0.1 \pm 0.2$ & 1.0 & 0.90 & 102 & 12 July \\
\hline \multirow[t]{2}{*}{ MVK } & $0.84 \pm 0.02$ & $0.7 \pm 0.1$ & 1.8 & 0.88 & 151 & 7 July \\
\hline & $1.02 \pm 0.02$ & $0.7 \pm 0.1$ & 1.0 & 0.91 & 150 & 2 August \\
\hline \multirow[t]{3}{*}{ MACR } & $1.08 \pm 0.02$ & $-0.9 \pm 0.1$ & 0.9 & 0.93 & 164 & 28 June \\
\hline & $1.15 \pm 0.03$ & $-1.1 \pm 0.2$ & 1.0 & 0.90 & 161 & 11 July \\
\hline & $1.00 \pm 0.04$ & $0.5 \pm 0.1$ & 0.8 & 0.84 & 139 & 11 August \\
\hline benzene & $1.00 \pm 0.05$ & $-0.1 \pm 0.1$ & 0.8 & 0.77 & 130 & 1 August \\
\hline mesitylene & $0.90 \pm 0.04$ & $0.0 \pm 0.1$ & 1.1 & 0.73 & 179 & 3 August \\
\hline mesitylene & $1.03 \pm 0.02$ & $0.8 \pm 0.1$ & 1.2 & 0.91 & 140 & 10 August \\
\hline toluene & $0.95 \pm 0.03$ & $1.0 \pm 0.1$ & 1.1 & 0.85 & 136 & 4 August \\
\hline p-xylene & $0.90 \pm 0.03$ & $0.5 \pm 0.1$ & 1.0 & 0.87 & 129 & 7 August \\
\hline all & $1.02 \pm 0.01$ & $0.10 \pm 0.03$ & 1.4 & 0.86 & 2495 & \\
\hline
\end{tabular}

* No addition of $\mathrm{OH}$ reactants.

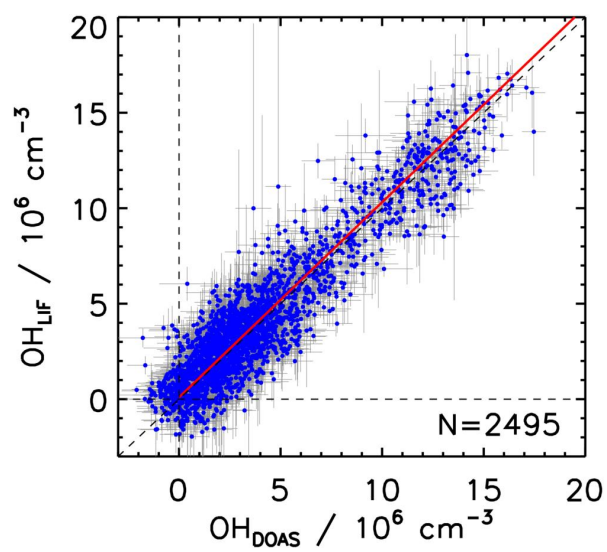

Fig. 4. Correlation of all $\mathrm{OH}$ concentration measurements by DOAS and LIF during SAPHIR experiments in summer 2011. LIF data are averaged to the time resolution of DOAS measurements. Grey bars are $1 \sigma$ errors of measurements. The red line gives the result of the regression analysis (slope: $1.02 \pm 0.01$, intercept $\left.(0.10 \pm 0.03) \times 10^{6} \mathrm{~cm}^{-3}, R^{2}=0.86\right)$. comparisons of the Jülich LIF and DOAS instruments. Both instruments measured together during two SAPHIR chamber campaigns in 2003 (Schlosser et al., 2007) and 2005 (HOxCOMP campaign, Schlosser et al., 2009). These two comparisons showed good agreement between $\mathrm{OH}$ concentrations of both instruments. The slopes of the regression $(0.99 \pm 0.13$ and $0.95 \pm 0.02$, respectively) and the insignificant intercepts demonstrated the high quality of measurements. Both instruments were also deployed during the field campaign POPCORN in 1994. The slope of the regression was $1.09 \pm 0.12$ for this campaign (Hofzumahaus et al., 1998). Results from the previous campaigns and this work give confidence that the calibration procedure of the LIF instrument is reliable.

Interferences from species that are not regularly present in high concentrations may not be easily detected in the regression analysis of entire data sets of field campaigns. The present study allows investigation of potential artifacts in LIF OH measurements in photochemically processed air, which contains specific biogenic or anthropogenic VOCs, because $\mathrm{OH}$ measurements by DOAS are not spectroscopically disturbed by unknown absorptions of organic species. Figure 6 shows the median, the 25 and 75 percentiles, and the 


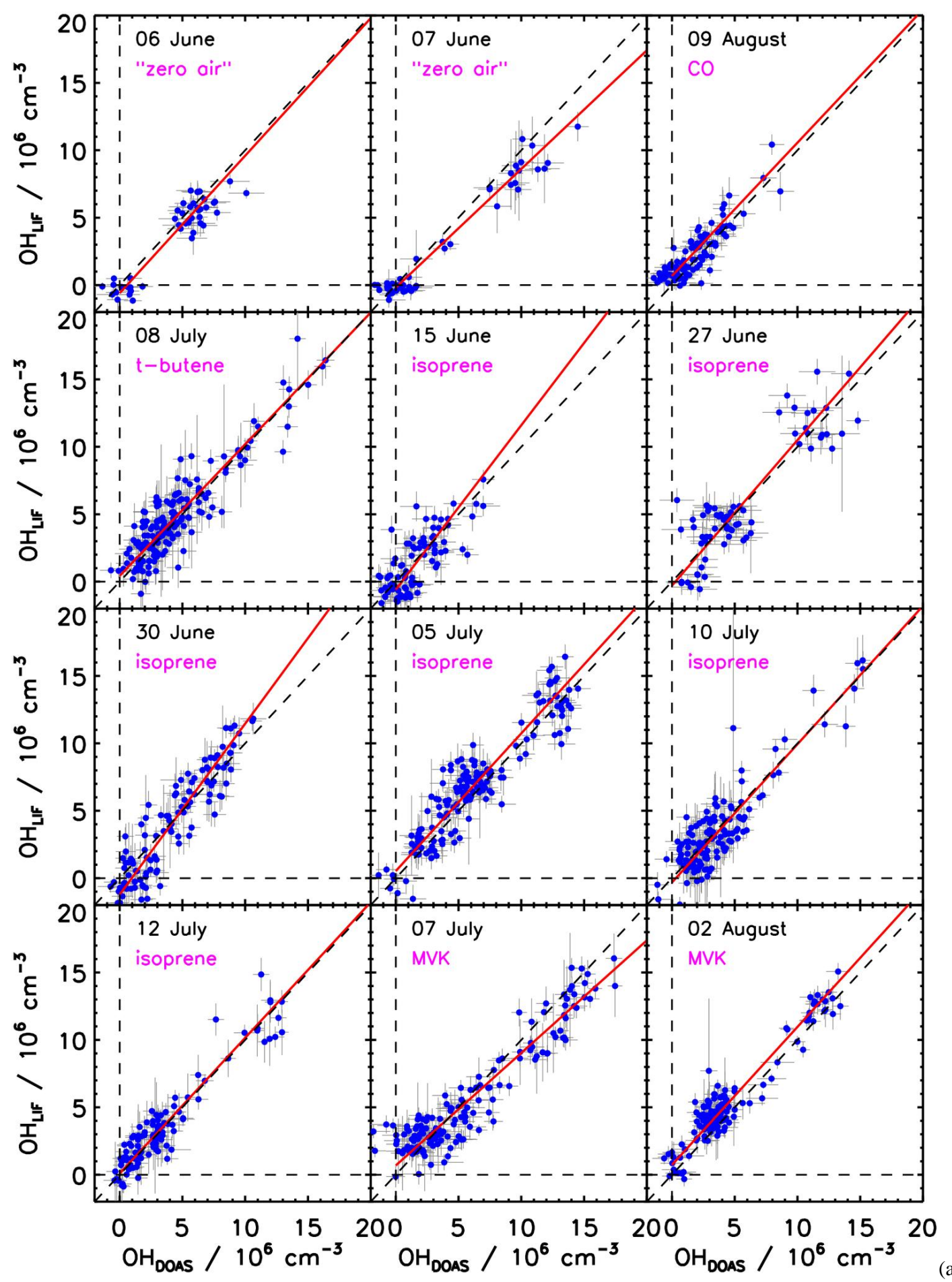

Fig. 5. Caption on next page.

mean with its error of the relative difference of $\mathrm{OH}$ measurements, dependening on the actual concentrations of the parent VOCs during the experiment runs. $\mathrm{OH}$ concentrations of less than $0.5 \times 10^{6} \mathrm{~cm}^{-3}$ are excluded from this analysis. Because of a sufficiently large number of measurements for experiments with isoprene and MACR, these data sets can be divided into four bins of increasing VOC concentration. In all other cases, data are assigned only to two bins (with and without the added VOC).

The statistical analysis clearly shows that there is no evidence for an interference in LIF measurements during the degradation of isoprene and MACR. Median values for these 


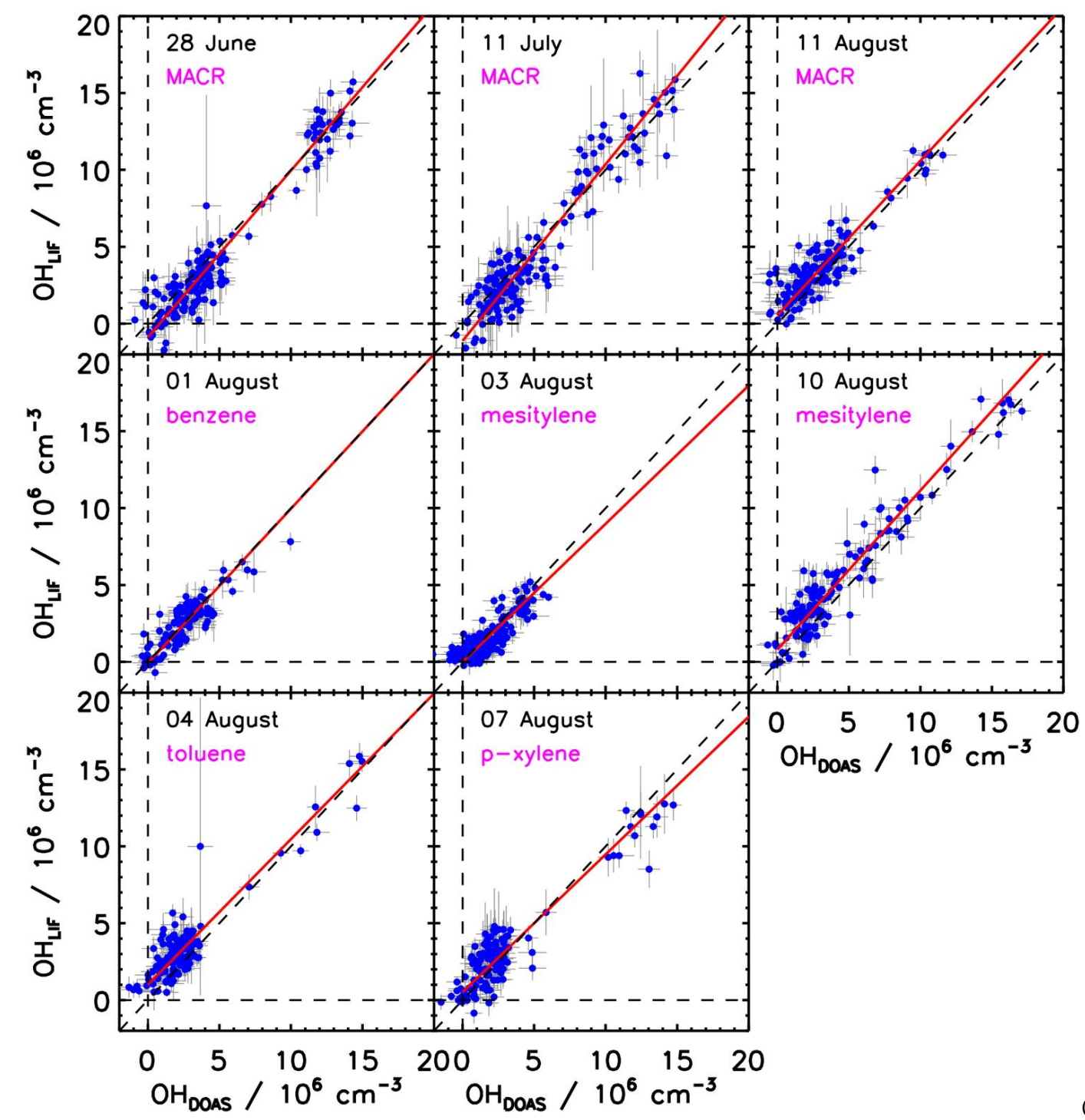

Fig. 5. Correlation of $\mathrm{OH}$ concentration measurements by DOAS and LIF for individual experiments. LIF data are averaged to the time resolution of DOAS measurements. Red lines give the result of the regression analysis shown in Table 3. No OH reactant was added during "zero air" experiments.

data subsets are around zero within 20 and $10 \%$, respectively, without a trend with increasing VOC concentration. Data within the 25 to 75 percentiles are equally distributed around zero. The increasing size of the 25 to 75 percentile boxes for isoprene is mostly due to the decreasing number of data points which are available at higher isoprene concentrations. Also for benzene, mesitylene, and p-xylene, no significant difference between LIF and DOAS measurements in the absence and presence of the $\mathrm{OH}$ reactant is observed. $\mathrm{t}$ Butene was added only during one experiment. Its concentration decreased quickly because of its fast reaction with $\mathrm{OH}$, so that only 30 data points are included in the box with tbutene mixing ratios larger than 0.5 ppbv. The positive median of the relative differences in the presence of t-butene shown in Fig. 6 is not significant, as also indicated by the large difference between the 25 and 75 percentiles and the error of the mean value.

For MVK and toluene, the median and 25 to 75 percentiles are only centered around zero in the absence of the VOC (leftmost box), but median, 25 and 75 percentiles are greater than zero when these compounds are present. $\mathrm{OH}$ concentrations measured by LIF are on average $40 \%$ larger than those by DOAS in the presence of 40 to $100 \mathrm{ppbv}$ toluene, and $30 \%$ larger in the presence of up to $20 \mathrm{ppbv}$ MVK. This can also be seen in the diurnal variation in Fig. $5 \mathrm{a}$ and $\mathrm{b}$ and appears as significant intercepts of approximately $1 \times 10^{6} \mathrm{~cm}^{-3}$ in the regression analysis (Table 3 ). The difference hints to a potential interference in LIF measurements, but cannot be proven 

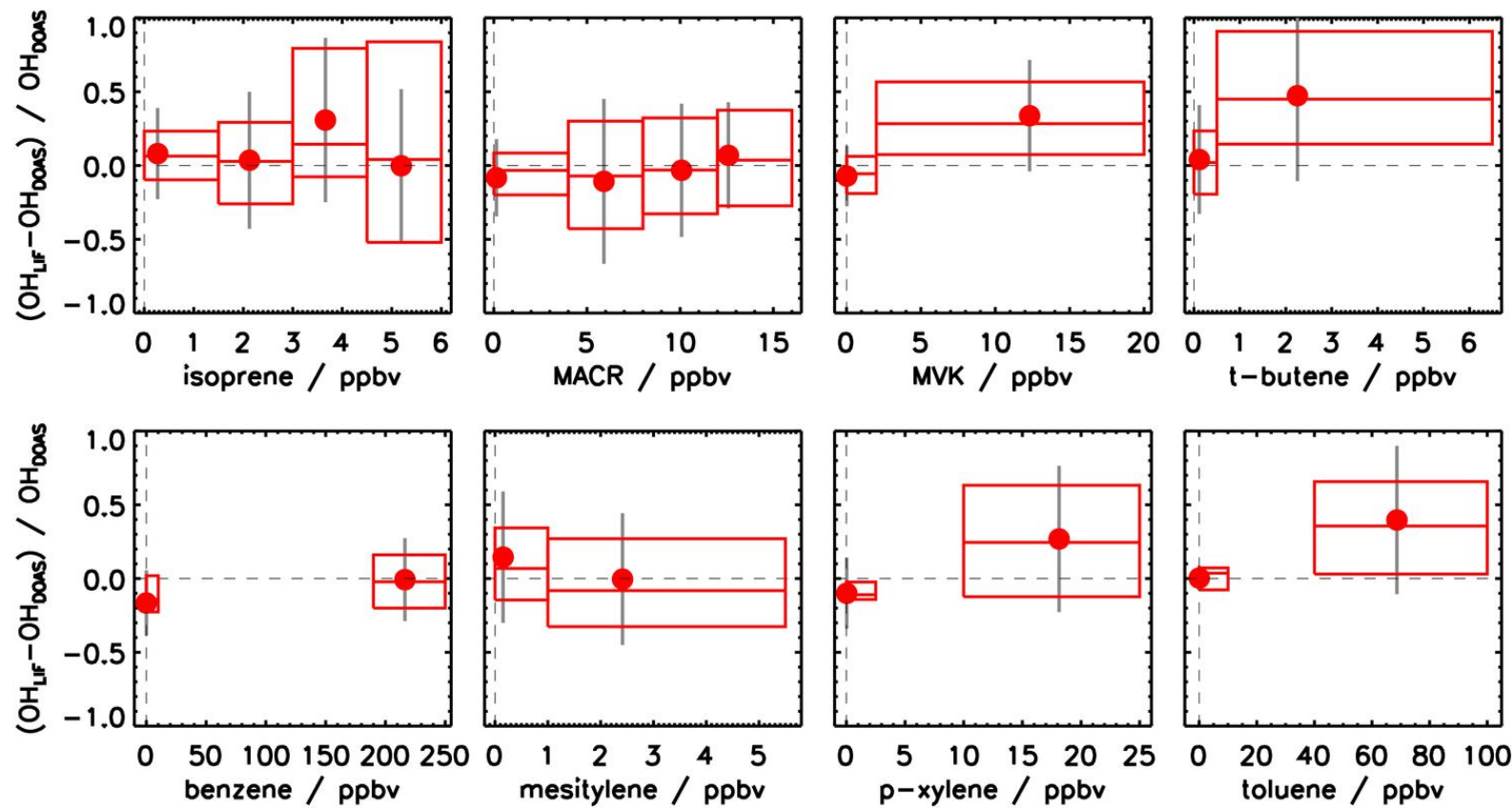

Fig. 6. Dependence of the relative difference between $\mathrm{OH}$ concentrations measured by LIF and DOAS on the VOC concentration measured over the course of the experiments. Red horizontal lines are the median and boxes give the 25 and 75 percentiles. Red dots are mean values with standard errors in grey bars. They are plotted at the mean of the VOC concentrations, which are analyzed within each bin.

from these experiments for two reasons. (1) Standard errors of the mean values indicate that the deviation from zero is only significant within $1 \sigma$. (2) Experiments with MVK and toluene were only done once and twice, respectively, so that a day-to-day variability in the performance of either one of the instruments cannot be excluded. Further investigations are needed to clarify the significance of a potential interference from these compounds or their oxidation products.

In principle, an interference that is observed during experiments with only MVK must also be observed during experiments investigating the photochemical degradation of isoprene because MVK is a first-generation product of the isoprene oxidation. However, MVK concentrations during experiments with isoprene were much smaller than in experiments in which only MVK was investigated. Maximum MVK mixing ratios were a few ppbv because: (1) isoprene concentrations needed to achieve the required $\mathrm{OH}$ reactivity were relatively small, (2) the yield of MVK from isoprene oxidation is only 30 to $40 \%$ (Karl et al., 2006), and (3) only part of the added isoprene was oxidized over the course of the experiment. Therefore, a potential interference from MVK oxidation would have been very small during experiments with isoprene.

The study by Mao et al. (2012) reveals a significant interference of about a factor of two in the $\mathrm{OH}$ measurements performed by the Pennstate GTHOS LIF instrument in a California forest during BEARPEX09. Apparently, the interference is caused by $\mathrm{OH}$ radicals that are produced internally in the instrument. Though the production mechanism is not clear, it is likely related to reactions of biogenic VOCs or of their oxidation products in the instrument. In contrast, our study finds generally good agreement of $\mathrm{OH}$ measurements by LIF and DOAS in experiments involving the oxidation of various alkenes (including isoprene) and aromatics by $\mathrm{OH}$. Our different result may be caused by the different design and operating conditions of the Jülich instrument compared to the Pennstate instrument. For example, the distance between the tip of the inlet and fluorescence detection in the GTHOS is longer than in the Jülich LIF instrument, prolonging the reaction time for potential $\mathrm{OH}$ formation. Another major difference is that $\mathrm{OH}$ excitation is accomplished by multiple passes of the laser beam in the GTHOS, but only a single pass in the Jülich instrument. Furthermore, differences in the VOC composition during BEARPEX09 and experiments in this work could cause different interferences. Here, experiments were performed at temperatures between $293 \mathrm{~K}$ and $303 \mathrm{~K}$ without a notable dependence of the relationship between LIF and DOAS measurements on temperature. In contrast, Mao et al. (2012) observed a strong temperaturedependent increase of the $\mathrm{OH}$ interference in their GTHOS instrument over the same range of temperatures. Though we consider an $\mathrm{OH}$ interference to be an unlikely explanation for unexpected high $\mathrm{OH}$ observations during PRIDE-PRD2006, we will continue our studies of potential artifacts by (oxygenated) VOCs. Further tests will include a titration approach similar to that reported by Mao et al. (2012).

During the PRIDE-PRD2006 campaign, isoprene and its oxidation products, alkenes and aromatic compounds were 
the main $\mathrm{OH}$ reactants during periods when measured $\mathrm{OH}$ concentrations were three to five times larger than predicted by models (Lou et al., 2010; Lu et al., 2012a). Despite the measurement uncertainties mentioned above, it is clear that any difference between LIF and DOAS measurements that is observed in the SAPHIR experiments is too small to explain the model-measurement discrepancies during the PRIDEPRD2006 campaign. In particular, there is no evidence for measurement artifacts connected to the degradation of isoprene, which made up a large part of the $\mathrm{OH}$ reactivity at PRD. A potential interference from MVK and toluene of the magnitude observed here would not have had a large impact on OH measurements during PRIDE-PRD2006, because their concentrations were much smaller (about a factor of 10) than during the SAPHIR experiments. Other compounds that can be excluded to be potential interferences in the LIF detection are $\mathrm{SO}_{2}$ and $\mathrm{HCHO}$, both of which absorb at $308 \mathrm{~nm}$. Previous comparisons between LIF and DOAS showed very good agreement in the presence of up to $16 \mathrm{ppbv} \mathrm{SO}_{2}$ during the POPCORN field campaign (Brandenburger et al., 1998; Hofzumahaus et al., 1998) and in the presence of up to $40 \mathrm{ppbv}$ HCHO during SAPHIR experiments (Schlosser et al., 2007). $\mathrm{SO}_{2}$ and $\mathrm{HCHO}$ concentrations did not exceed these levels during PRIDE-PRD2006.

\section{Summary and conclusions}

In summer 2011 experiments were carried out in the atmosphere simulation chamber SAPHIR in Jülich, Germany, in order investigate the degradation of several VOCs (isoprene, MVK, MACR, and aromatic compounds) for conditions of high $\mathrm{OH}$ loss rates and low $\mathrm{NO}_{\mathrm{x}}$ concentrations. An additional benefit of the chamber experiments was the simultaneous detection of $\mathrm{OH}$ by two independent instruments (DOAS and LIF), which apply different techniques. DOAS measurements do not require a calibration in contrast to those by LIF, so that LIF measurements can be compared to a reference standard.

The analysis of data shows excellent agreement between the measurements of the DOAS and LIF instruments. The regression analysis of the entire data set at the time resolution of the DOAS data gives unity slope ( $1 \sigma$ accuracies of measurements are $6.5 \%$ and $10 \%$ for DOAS and LIF, respectively). Similar results were achieved during earlier comparisons in the field (Hofzumahaus et al., 1998) and in the SAPHIR chamber (Schlosser et al., 2007, 2009). This gives strong confidence that the sensitivity of the LIF instrument is well-defined by the calibration procedure using the Jülich radical source, which produces $\mathrm{OH}$ by water vapor photolysis at $185 \mathrm{~nm}$. The long record of good agreement between LIF and DOAS demonstrates the long-term stability of the calibration procedure.

During experiments with high isoprene, MACR, and most of the aromatic compounds, no systematic deviations between measurements by LIF and DOAS are observed. During two experiments with MVK and one experiment with toluene, the statistical analysis shows that $\mathrm{OH}$ concentrations by LIF are $30 \%$ to $40 \%$ larger than those by DOAS after the VOC has been injected into the chamber. This could be a hint for an artifact in the LIF measurements, but the significance of this result is not clear from these experiments. Further investigations are needed to clarify this point.

No hints for interferences in LIF data were also observed in earlier comparisons. Here, it is shown that this also holds for the specific conditions of high $\mathrm{OH}$ reactivity due to isoprene and aromatic compounds and low NO concentrations. These are conditions that were encountered during the PRIDE-PRD2006 campaign (Hofzumahaus et al., 2009; Lu et al., 2012a). Results of this comparison indicate that the discrepancy between $\mathrm{OH}$ measurements and model calculations observed in PRD is most likely not caused by artifacts in the LIF measurements. Contributions from potential interferences from MVK and toluene, which cannot be excluded from these SAPHIR experiments, would be by far too small to explain the missing OH source during PRIDE-PRD2006.

SAPHIR experiments will be further investigated with respect to the question whether measured $\mathrm{OH}$ concentrations during the photochemical degradation of isoprene, MVK, MACR and aromatic compounds can be reproduced by chemical models. The good agreement between two independent $\mathrm{OH}$ instruments provides confidence in the high quality of their measurements. This is an essential prerequisite for the interpretation of the experiments.

Acknowledgements. This work was supported by the EU FP-7 program EUROCHAMP-2 (grant agreement no. 228335) and by the EU FP-7 program PEGASOS (grant agreement no. 265307). S. Nehr and B. Bohn thank the Deutsche Forschungsgemeinschaft for funding under grant BO 1580/3-1. We thank M. Kaminski, R. Wegener, K. D. Lu, X. Li, A. Buchholz, P. Schlag, H.-C. Wu, S. Dixneuf, P. Müsgen and R. Häseler for additional measurements during this campaign and technical support.

The service charges for this open access publication have been covered by a Research Centre of the Helmholtz Association.

Edited by: D. Heard 


\section{References}

Apel, E. C., Brauers, T., Koppmann, R., Bandowe, B., Bossmeyer, J., Holzke, C., Tillmann, R., Wahner, A., Wegener, R., Brunner, A., Jocher, M., Ruuskanen, T., Spirig, C., Steigner, D., Steinbrecher, R., Gomez Alvarez, E., Müller, K., Burrows, J. P., Schade, G., Solomon, S. J., Ladstätter-Weissenmayer, A., Simmonds, P., Young, D., Hopkins, J. R., Lewis, A. C., Legreid, G., Reimann, S., Hansel, A., Wisthaler, A., Blake, R. S., Ellis, A. M., Monks, P. S., and Wyche, K. P.: Intercomparison of oxygenated volatile organic compound measurements at the SAPHIR atmosphere simulation chamber, J. Geophys. Res., 113, D20307, doi:10.1029/2008JD009865, 2008.

Aschmutat, U., Hessling, M., Holland, F., and Hofzumahaus, A.: A tunable source of hydroxyl $(\mathrm{OH})$ and hydroperoxy $\left(\mathrm{HO}_{2}\right)$ radicals: In the range between $10^{6}$ and $10^{9} \mathrm{~cm}^{-3}$, Physicochemical behaviour of atmospheric pollutants, European Commission, Brussels, 1994.

Barmet, P., Dommen, J., DeCarlo, P. F., Tritscher, T., Praplan, A. P., Platt, S. M., Prévôt, A. S. H., Donahue, N. M., and Baltensperger, U.: $\mathrm{OH}$ clock determination by proton transfer reaction mass spectrometry at an environmental chamber, Atmos. Meas. Tech., 5, 647-656, doi:10.5194/amt-5-647-2012, 2012.

Beck, S. M., Bendura, R. J., McDougal, D. S., Hoell, J. M., Gregory, G. L., Curfman, H. J., Davis, D. D., Bradshaw, J., Rodgers, M. O., Wang, C. C., Davis, L. I., Campbell, M. J., Torres, A. L., Carroll, M. A., Ridley, B. A., Sachse, G. W., Hill, G. F., Condon, E. P., and Rasmussen, R. A.: Operational overview of NASA GTE/CITE 1 airborne instrument intercomparisons: carbon monoxide, nitric oxide, and hydroxyl instrumentation, J. Geophys. Res., 92, 1977-1985, 1987.

Bohn, B., Rohrer, F., Brauers, T., and Wahner, A.: Actinometric measurements of $\mathrm{NO}_{2}$ photolysis frequencies in the atmosphere simulation chamber SAPHIR, Atmos. Chem. Phys., 5, 493-503, doi:10.5194/acp-5-493-2005, 2005.

Bousquet, P., Hauglustaine, D. A., Peylin, P., Carouge, C., and Ciais, P.: Two decades of $\mathrm{OH}$ variability as inferred by an inversion of atmospheric transport and chemistry of methyl chloroform, Atmos. Chem. Phys., 5, 2635-2656, doi:10.5194/acp-52635-2005, 2005.

Brandenburger, U., Brauers, T., Dorn, H.-P., Hausmann, M., and Ehhalt, D. H.: In-situ measurements of tropospheric hydroxyl radicals by folded long-path laser absorption during the field campaign POPCORN, J. Atmos. Chem., 31, 181-204, 1998.

Brauers, T., Hausmann, M., Brandenburger, U., and Dorn, H.-P.: Improvement of differential optical absorption spectroscopy with a multichannel scanning technique, Appl. Optics, 34, 44724479, 1995.

Brauers, T., Aschmutat, U., Brandenburger, U., Dorn, H.-P., Hausmann, M., Hessling, M., Hofzumahaus, A., Holland, F., PlassDülmer, C., and Ehhalt, D. H.: Intercomparison of tropospheric $\mathrm{OH}$ radical measurements by multiple folded long-path laser absorption and laser induced fluorescence, Geophys. Res. Lett., 23, 2545-2548, 1996.

Brauers, T., Hausmann, M., Bister, A., Kraus, A., and Dorn, H.-P.: $\mathrm{OH}$ radicals in the boundary layer of the Atlantic Ocean 1. Measurements by long-path laser absorption spectroscopy, J. Geophys. Res., 106, 7399-7414, 2001.
Campbell, M. J., Hall, B. D., Sheppard, J. C., Utley, P. L., O’Brien, R. J., Hard, T. M., and George, L. A.: Intercomparison of local hydroxyl measurements by radiocarbon and FAGE techniques, J. Atmos. Sci., 52, 3421-3428, 1995.

Dorn, H. P., Neuroth, R., and Hofzumahaus, A.: Investigation of $\mathrm{OH}$ absorption cross sections of rotational transitions in the $A^{2} \Sigma^{+}$, $v^{\prime}=0 \leftarrow X^{2} \Pi, v^{\prime \prime}=0$ band under atmospheric conditions: Implications for tropospheric long-path absorption measurements, J. Geophys. Res., 100, 7397-7409, 1995.

Ehhalt, D. H. and Rohrer, F.: Dependence of the $\mathrm{OH}$ concentration on solar UV, J. Geophys. Res., 105, 3565-3571, 2000.

Eisele, F. L. and Tanner, D. J.: Ion assisted tropospheric OH measurements, J. Geophys. Res., 96, 9295-9308, 1991.

Eisele, F. L., Mauldin, R. L., Tanner, D. J., Cantrell, C., Kosciuch, E., Nowak, J. B., Brune, B., Faloona, I., Tan, D., Davis, D. D., Wang, L., and Chen, G.: Relationship between $\mathrm{OH}$ measurements on two different NASA aircraft during PEM Tropics B, J. Geophys. Res., 106, 32683-32689, 2001.

Finlayson-Pitts, B. J. and Pitts Jr., J. N.: Chemistry of the upper and lower atmosphere, Academic Press, San Diego, 2000.

Fuchs, H., Brauers, T., Häseler, R., Holland, F., Mihelcic, D., Müsgen, P., Rohrer, F., Wegener, R., and Hofzumahaus, A.: Intercomparison of peroxy radical measurements obtained at atmospheric conditions by laser-induced fluorescence and electron spin resonance spectroscopy, Atmos. Meas. Tech., 2, 55-64, doi:10.5194/amt-2-55-2009, 2009.

Fuchs, H., Ball, S. M., Bohn, B., Brauers, T., Cohen, R. C., Dorn, H.-P., Dubé, W. P., Fry, J. L., Häseler, R., Heitmann, U., Jones, R. L., Kleffmann, J., Mentel, T. F., Müsgen, P., Rohrer, F., Rollins, A. W., Ruth, A. A., Kiendler-Scharr, A., Schlosser, E., Shillings, A. J. L., Tillmann, R., Varma, R. M., Venables, D. S., Villena Tapia, G., Wahner, A., Wegener, R., Wooldridge, P. J., and Brown, S. S.: Intercomparison of measurements of $\mathrm{NO}_{2}$ concentrations in the atmosphere simulation chamber SAPHIR during the NO3Comp campaign, Atmos. Meas. Tech., 3, 21-37, doi:10.5194/amt-3-21-2010, 2010a.

Fuchs, H., Brauers, T., Dorn, H.-P., Harder, H., Häseler, R., Hofzumahaus, A., Holland, F., Kanaya, Y., Kajii, Y., Kubistin, D., Lou, S., Martinez, M., Miyamoto, K., Nishida, S., Rudolf, M., Schlosser, E., Wahner, A., Yoshino, A., and Schurath, U.: Technical Note: Formal blind intercomparison of $\mathrm{HO}_{2}$ measurements in the atmosphere simulation chamber SAPHIR during the HOxComp campaign, Atmos. Chem. Phys., 10, 12233-12250, doi:10.5194/acp-10-12233-2010, 2010 .

Fuchs, H., Bohn, B., Hofzumahaus, A., Holland, F., Lu, K. D., Nehr, S., Rohrer, F., and Wahner, A.: Detection of $\mathrm{HO}_{2}$ by laserinduced fluorescence: calibration and interferences from $\mathrm{RO}_{2}$ radicals, Atmos. Meas. Tech., 4, 1209-1225, doi:10.5194/amt4-1209-2011, 2011.

Hausmann, M., Brandenburger, U., Brauers, T., and Dorn, H.-P.: Detection of tropospheric $\mathrm{OH}$ radicals by long-path differentialoptical-absorption spectroscopy: Experimental setup, accuracy, and precision, J. Geophys. Res., 102, 16011-16022, 1997.

Hausmann, M., Brandenburger, U., Brauers, T., and Dorn, H.-P.: Simple Monte Carlo methods to estimate the spectra evaluation error in differential-optical-absorption spectroscopy, Appl. Optics, 38, 462-475, 1999. 
Heard, D. E. and Henderson, D. A.: Quenching of $\mathrm{OH}\left(\mathrm{A}^{2} \sum^{+}\right.$, $v^{\prime}=0$ ) several collision partners between 200 and $344 \mathrm{~K}$, Crosssection measurements and model comparisons, Phys. Chem. Chem. Phys., 2, 67-72, 2000.

Heard, D. E. and Pilling, M. J.: Measurement of $\mathrm{OH}$ and $\mathrm{HO}_{2}$ in the troposphere, Chem. Rev., 103, 5163-5198, 2003.

Hofzumahaus, A., Aschmutat, U., Brandenburger, U., Brauers, T., Dorn, H.-P., Hausmann, M., Hessling, M., Holland, F., PlassDülmer, C., and Ehhalt, D. H.: Intercomparison of tropospheric $\mathrm{OH}$ measurements by different laser techniques during the POPCORN campaign 1994, J. Atmos. Chem., 31, 227-246, 1998.

Hofzumahaus, A., Rohrer, F., Lu, K., Bohn, B., Brauers, T., Chang, C.-C., Fuchs, H., Holland, F., Kita, K., Kondo, Y., Li, X., Lou, S., Shao, M., Zeng, L., Wahner, A., and Zhang, Y.: Amplified trace gas removal in the troposphere, Science, 324, 1702-1704, 2009.

Holland, F., Hofzumahaus, A., Schäfer, J., Kraus, A., and Pätz, H. W.: Measurements of $\mathrm{OH}$ and $\mathrm{HO}_{2}$ radical concentrations and photolysis frequencies during BERLIOZ, J. Geophys. Res., 108, 8246, doi:10.1029/2001JD001393, 2003.

Karl, M., Dorn, H. P., Holland, F., Koppmann, R., Poppe, D., Rupp, L., Schaub, A., and Wahner, A.: Product study of the reaction of $\mathrm{OH}$ radicals with isoprene in the atmosphere simulation chamber SAPHIR, J. Atmos. Chem., 55, 167-187, 2006.

Kubistin, D., Harder, H., Martinez, M., Rudolf, M., Sander, R., Bozem, H., Eerdekens, G., Fischer, H., Gurk, C., Klüpfel, T., Königstedt, R., Parchatka, U., Schiller, C. L., Stickler, A., Taraborrelli, D., Williams, J., and Lelieveld, J.: Hydroxyl radicals in the tropical troposphere over the Suriname rainforest: comparison of measurements with the box model MECCA, Atmos. Chem. Phys., 10, 9705-9728, doi:10.5194/acp-10-97052010, 2010.

Laj, P., Klausen, J., Bilde, M., Plass Dülmer, C., Pappalardo, G., Clerbaux, C., Baltensperger, U., Hjorth, J., Simpson, D., Reimann, S., Coheur, P. F., Richter, A., De Maziere, M., Rudich, Y., McFiggans, G., Torseth, K., Wiedensohler, A., Morin, S., Schulz, M., Allan, J. D., Attie, J. L., Barnes, I., Birmili, W., Cammas, J. P., Dommen, J., Dorn, H. P., Fowler, D., Fuzzi, S., Glasius, M., Granier, C., Hermann, M., Isaksen, I. S. A., Kinne, S., Koren, I., Madonna, F., Maione, M., Massling, A., Moehler, O., Mona, L., Monks, P. S., Müller, D., Müller, T., Orphal, J., Peuch, V. H., Stratmann, F., Tanre, D., Tyndall, G., Abo Riziq, A., van Roozendael, M., Villani, P., Wehner, B., Wex, H., and Zardini, A. A.: Measuring atmospheric composition change, Atmos. Environ., 43, 5351-5414, 2009.

Lelieveld, J., Butler, T. M., Crowley, J. N., Dillon, T. J., Fischer, H., Ganzeveld, L., Harder, H., Lawrence, M. G., Martinez, M., Taraborrelli, D., and Williams, J.: Atmospheric oxidation capacity sustained by a tropical forest, Nature, 452, 737-740, 2008.

Lou, S., Holland, F., Rohrer, F., Lu, K., Bohn, B., Brauers, T., Chang, C. C., Fuchs, H., Häseler, R., Kita, K., Kondo, Y., Li, X., Shao, M., Zeng, L., Wahner, A., Zhang, Y., Wang, W., and Hofzumahaus, A.: Atmospheric $\mathrm{OH}$ reactivities in the Pearl River Delta - China in summer 2006: measurement and model results, Atmos. Chem. Phys., 10, 11243-11260, doi:10.5194/acp-10-11243-2010, 2010.

Lu, K. D., Rohrer, F., Holland, F., Fuchs, H., Bohn, B., Brauers, T., Chang, C. C., Häseler, R., Hu, M., Kita, K., Kondo, Y., Li, X., Lou, S. R., Nehr, S., Shao, M., Zeng, L. M., Wahner, A., Zhang, Y. H., and Hofzumahaus, A.: Observation and modelling of $\mathrm{OH}$ and $\mathrm{HO}_{2}$ concentrations in the Pearl River Delta 2006: a missing $\mathrm{OH}$ source in a VOC rich atmosphere, Atmos. Chem. Phys., 12, 1541-1569, doi:10.5194/acp-12-1541-2012, 2012a.

Lu, K. D., Hofzumahaus, A., Holland, F., Bohn, B., Brauers, T., Fuchs, H., Hu, M., Häseler, R., Kita, K., Kondo, Y., Li, X., Lou, S. R., Oebel, A., Shao, M., Zeng, L. M., Wahner, A., Zhu, T., Zhang, Y. H., and Rohrer, F.: Missing OH source in a suburban environment near Beijing: observed and modelled $\mathrm{OH}$ and $\mathrm{HO}_{2}$ concentrations in summer 2006, Atmos. Chem. Phys. Discuss., 12, 10879-10936, doi:10.5194/acpd-12-10879-2012, 2012 b.

Mao, J., Ren, X., Brune, W. H., Van Duin, D. M., Cohen, R. C., Park, J.-H., Goldstein, A. H., Paulot, F., Beaver, M. R., Crounse, J. D., Wennberg, P. O., DiGangi, J. P., Henry, S. B., Keutsch, F. N., Park, C., Schade, G. W., Wolfe, G. M., and Thornton, J. A.: Insights into hydroxyl measurements and atmospheric oxidation in a California forest, Atmos. Chem. Phys. Discuss., 12, 67156744, doi:10.5194/acpd-12-6715-2012, 2012.

Monks, P. S., Granier, C., Fuzzi, S., Stohl, A., Williams, M. L., Akimoto, H., Amann, M., Baklanov, A., Baltensperger, U., Bey, I., Blake, N., Blake, R. S., Carslaw, K., Cooper, O. R., Dentener, F., Fowler, D., Fragkou, E., Frost, G. J., Generoso, S., Ginoux, P., Grewe, V., Guenther, A., Hansson, H. C., Henne, S., Hjorth, J., Hofzumahaus, A., Huntrieser, H., Isaksen, I. S. A., Jenkin, M. E., Kaiser, J., Kanakidou, M., Klimont, Z., Kulmala, M., Laj, P., Lawrence, M. G., Lee, J. D., Liousse, C., Maione, M., McFiggans, G., Metzger, A., Mieville, A., Moussiopoulos, N., Orlando, J. J., O'Dowd, C. D., Palmer, P. I., Parrish, D. D., Petzold, A., Platt, U., Pöschl, U., Prevot, A. S. H., Reeves, C. E., Reimann, S., Rudich, Y., Sellegri, K., Steinbrecher, R., Simpson, D., ten Brink, H., Theloke, J., van der Werf, G. R., Vautard, R., Vestreng, V., Vlachokostas, C., and von Glasow, R.: Atmospheric composition change - global and regional air quality, Atmos. Environ., 43, 5268-5350, 2009.

Mount, G. H., Eisele, F. L., Tanner, D. J., Brault, J. W., Johnston, P. V., Harder, J. W., Williams, E. J., Fried, A., and Shetter, R.: An intercomparison of spectroscopic laser long-path and ionassisted in situ measurements of hydroxyl concentrations during the Tropospheric OH Photochemistry Experiment, fall 1993, J. Geophys. Res., 102, 6437-6455, 1997.

Poppe, D., Brauers, T., Dorn, H.-P., Karl, M., Mentel, T., Schlosser, E., Tillmann, R., Wegener, R., and Wahner, A.: OH-initiated degradation of several hydrocarbons in the atmosphere simulation chamber SAPHIR, J. Atmos. Chem., 57, 203-214, 2007.

Press, W. H., Teukolsky, S. A., Vetterling, W. T., and Flannery, B. P.: Numerical recipies in C, 2nd Edn., Cambridge University Press, 1992.

Prinn, R. G., Huang, J., Weiss, R. F., Cunnold, D. M., Fraser, P. J., Simmonds, P. G., McCulloch, A., Harth, C., Reimann, S., Salameh, P., O’Doherty, S., Wang, R. H. J., Porter, L. W., Miller, B. R., and Krummel, P. B.: Evidence for variability of atmospheric hydroxyl radicals over the past quarter century, Geophys. Res. Lett., 32, L07809, doi:10.1029/2004g1022228, 2005.

Pugh, T. A. M., MacKenzie, A. R., Hewitt, C. N., Langford, B., Edwards, P. M., Furneaux, K. L., Heard, D. E., Hopkins, J. R., Jones, C. E., Karunaharan, A., Lee, J., Mills, G., Misztal, P., Moller, S., Monks, P. S., and Whalley, L. K.: Simulating atmospheric composition over a South-East Asian tropical rainforest: performance of a chemistry box model, Atmos. Chem. Phys., 10, 279-298, doi:10.5194/acp-10-279-2010, 2010. 
Ren, X., Olson, J. R., Crawford, J. H., Brune, W. H., Mao, J., Long, R. B., Chen, Z., Chen, G., Avery, M. A., Sachse, G. W., Barrick, J. D., Diskin, G. S., Huey, L. G., Fried, A., Cohen, R. C., Heikes, B., Wennberg, P. O., Singh, H. B., Blake, D. R., and Shetter, R. E.: $\mathrm{HO}_{\mathrm{x}}$ chemistry during INTEX-A 2004: Observation, model calculation, and comparison with previous studies, J. Geophys. Res., 113, D05310, doi:10.1029/2007JD009166, 2008.

Rohrer, F. and Berresheim, H.: Strong correlation between levels of tropospheric hydroxyl radicals and solar ultraviolet radiation, Nature, 442, 184-187, 2006.

Rohrer, F., Bohn, B., Brauers, T., Brüning, D., Johnen, F.-J., Wahner, A., and Kleffmann, J.: Characterisation of the photolytic HONO-source in the atmosphere simulation chamber SAPHIR, Atmos. Chem. Phys., 5, 2189-2201, doi:10.5194/acp-5-21892005, 2005.

Schlosser, E., Bohn, B., Brauers, T., Dorn, H.-P., Fuchs, H., Häseler, R., Hofzumahaus, A., Holland, F., Rohrer, F., Rupp, L. O., Siese, M., Tillmann, R., and Wahner, A.: Intercomparison of two hydroxyl radical measurement techniques at the atmosphere simulation chamber SAPHIR, J. Atmos. Chem., 56, 187-205, 2007.

Schlosser, E., Brauers, T., Dorn, H.-P., Fuchs, H., Häseler, R., Hofzumahaus, A., Holland, F., Wahner, A., Kanaya, Y., Kajii, Y., Miyamoto, K., Nishida, S., Watanabe, K., Yoshino, A., Kubistin, D., Martinez, M., Rudolf, M., Harder, H., Berresheim, H., Elste, T., Plass-Dülmer, C., Stange, G., and Schurath, U.: Technical Note: Formal blind intercomparison of $\mathrm{OH}$ measurements: results from the international campaign HOxComp, Atmos. Chem. Phys., 9, 7923-7948, doi:10.5194/acp-9-7923-2009, 2009.
Tan, D., Faloona, I., Simpas, J. B., Brune, W., Shepson, P. B., Couch, T. L., Summer, A. L., Carroll, M. A., Thornberry, T., Apel, E., Riemer, D., and Stockwell, W.: $\mathrm{HO}_{\mathrm{x}}$ budget in a deciduous forest: results from the PROPHET summer 1998 campaign, J. Geophys. Res., 106, 24407-24427, 2001.

Whalley, L. K., Furneaux, K. L., Goddard, A., Lee, J. D., Mahajan, A., Oetjen, H., Read, K. A., Kaaden, N., Carpenter, L. J., Lewis, A. C., Plane, J. M. C., Saltzman, E. S., Wiedensohler, A., and Heard, D. E.: The chemistry of $\mathrm{OH}$ and $\mathrm{HO}_{2}$ radicals in the boundary layer over the tropical Atlantic Ocean, Atmos. Chem. Phys., 10, 1555-1576, doi:10.5194/acp-10-1555-2010, 2010.

Whalley, L. K., Edwards, P. M., Furneaux, K. L., Goddard, A., Ingham, T., Evans, M. J., Stone, D., Hopkins, J. R., Jones, C. E., Karunaharan, A., Lee, J. D., Lewis, A. C., Monks, P. S., Moller, S. J., and Heard, D. E.: Quantifying the magnitude of a missing hydroxyl radical source in a tropical rainforest, Atmos. Chem. Phys., 11, 7223-7233, doi:10.5194/acp-11-7223-2011, 2011. 